DOI: $10.29303 /$ jrpb.v8i2.180

ISSN 2301-8119, e-ISSN 2443-1354

Tersedia online di http://jrpb.unram.ac.id/

\title{
PENGARUH JENIS KEMASAN DAN SUHU PENYIMPANAN TERHADAP KARAKTERISTIK FISIK JAGUNG MANIS SEGAR (Zea mays L.)
}

\author{
Effect of Packaging Type and Storage Temperature on \\ Physical Characteristics of Fresh Sweet Corn (Zea mays L.)
}

\author{
Ansar*), Murad, Sukmawaty, Sarmini Wati \\ Program Studi Teknik Pertanian, Fakultas Teknologi Pangan dan Agroindustri \\ Universitas Mataram, Jl. Majapahit No. 62, Mataram 83125, Indonesia
}

Email ${ }^{*}$ : ansar72@unram.ac.id

Diterima: Juli 2020

Disetujui: September 2020

\begin{abstract}
Fresh sweet corn has a short shelf life of only 2-3 days if stored at room temperature. This short shelf life can reduce the quality and economic value of corn, therefore an effort to overcome this problem is needed. The purpose of this study was to study the effect of packaging type and storage temperature on the physical characteristics of fresh sweet corn (Zea mays L.) during storage. The research method was carried out by storing fresh sweet corn in PP and PE packaging at temperatures of 10 and $29^{\circ} \mathrm{C}$ for 10 days, then measuring moisture content, weight loss, and corn color chromaticity. The results showed that the water content of fresh sweet corn decreased during storage. The use of PP packaging at $10^{\circ} \mathrm{C}$ could inhibit the evaporation of sweet corn water content, so that the loss of water content was smaller at only $24.75 \%$ compared to PE packaging which was $25.81 \%$. The highest weight loss occurred at a storage temperature of $29^{\circ} \mathrm{C}$ without packaging which was $44.71 \%$ and the lowest weight loss occurred at a storage temperature of $10^{\circ} \mathrm{C}$ using PP packaging which was $26.77 \%$. The color of sweet corn fades with storage time. This type of PP packaging at a storage temperature of $10^{\circ} \mathrm{C}$ could maintain the freshness of fresh sweet corn during storage.
\end{abstract}

Keywords: fresh sweet corn; moisture content; weight loss; color

\begin{abstract}
ABSTRAK
Jagung manis segar memiliki umur simpan yang pendek, yaitu hanya 2-3 hari jika disimpan pada suhu kamar. Umur simpan yang pendek ini dapat menurunkan kualitas dan nilai ekonomis jagung, sehingga perlu ada upaya untuk mengatasinya. Tujuan penelitian ini adalah mempelajari pengaruh jenis kemasan dan suhu penyimpanan terhadap karakteristik fisik jagung manis segar (Zea mays L.) selama penyimpanan. Metode penelitian dilakukan dengan cara menyimpan jagung manis segar di dalam kemasan PP dan PE pada suhu 10 dan $29^{\circ} \mathrm{C}$ selama 10 hari, kemudian mengukur kadar air, susut bobot, dan kromasitas warna jagung. Hasil penelitian menunjukkan bahwa kadar air jagung manis segar selama penyimpanan mengalami penurunan. Penggunaan kemasan PP pada suhu $10^{\circ} \mathrm{C}$ dapat menghambat penguapan kadar air jagung manis, sehingga kehilangan kadar air lebih kecil sebesar $24,75 \%$ jika dibandingkan
\end{abstract}


dengan kemasan PE sebesar 25,81\%. Susut bobot tertinggi terjadi pada suhu penyimpanan $29^{\circ} \mathrm{C}$ tanpa kemasan sebesar $44,71 \%$ dan susut bobot terendah sebesar $26,77 \%$ terjadi pada suhu penyimpanan $10^{\circ} \mathrm{C}$ menggunakan kemasan PP. Warna jagung manis semakin pudar seiring dengan lamanya penyimpanan. Jenis kemasan $\mathrm{PP}$ pada suhu penyimpanan $10^{\circ} \mathrm{C}$ dapat mempertahankan kesegaran jagung manis segar selama penyimpanan.

Kata Kunci: jagung manis; kadar air; susut bobot; warna

\section{PENDAHULUAN}

Buah dan sayuran yang sudah dipanen pada umumnya mengalami perubahan kualitas selama penyimpanan (Lamona et al., 2015). Perubahan kualitas ini dipengaruhi oleh beberapa faktor, antara lain umur panen, suhu penyimpanan, bahan kemasan, dan penggunaan bahan pengawet (Nofriati \& Asni, 2015). Informasi tentang perubahan kualitas bahan pangan sangat penting diketahui untuk memberikan kepastian kepada konsumen sebelu Lamona $\mathrm{m}$ produk tersebut dikonsumsi (Amanto et al., 2011).

Jagung manis segar memiliki umur simpan yang sangat terbatas, yaitu hanya 23 hari jika disimpan pada suhu kamar (28$30^{\circ} \mathrm{C}$ ) (Lapanga et al., 2020). Umur simpan yang pendek ini merupakan masalah utama dalam penanganan pascapanen jagung manis segar. Jenis-jenis kerusakan yang terjadi dapat berpengaruh terhadap kualitas kesegaran jagung manis, sementara konsumen membutuhkan jagung manis dalam kondisi segar. Menurut Khathir et al. (2015) penurunan kualitas jagung manis dapat dihambat dengan menggunakan kemasan yang tepat.

Pengemasan yang tepat dapat menjaga produk tetap bersih dan melindungi dari kemungkinan kerusakan fisik dan mekanis (Maryani \& Pradiana, 2008). Selama ini pengemasan jagung manis segar biasanya dilakukan dengan menggunakan plastik yang memiliki permeabilitas uap air dan oksigen yang cukup rendah (Anggraini \& Sugiarti, 2018). Penggunaan plastik sebagai bahan kemasan, selain dapat menahan kelembaban dan mencegah kehilangan air, juga dapat melindungi dari kerusakan mekanis dan mencegah kontaminasi dengan debu (Hariadi et al., 2017).

Bahan hasil pertanian yang baru saja dipanen dapat disimpan pada suhu dingin untuk memperpanjang umur simpannya (Mareta \& Nur, 2011). Selain itu, penyimpanan pada suhu dingin dapat memperbaiki mutu produk dan menghindarkan dijual dalam keadaan segar (Dewi, 2015), memungkinkan tersedianya sayuran sepanjang tahun (Satmalawati \& Rusae, 2017), membantu pemasaran sayuran yang teratur (Sulthoni et al., 2016), dan mempertahankan mutu produk tetap dalam kondisi yang segar (Sari \& Hadiyanto, 2013). Penyimpanan suhu dingin pada prinsipnya dapat menekan laju respirasi, sehingga umur simpan buah dapat dipertahankan (Muhajir et al., 2014).

Masalah yang sering terjadi selama penyimpanan jagung manis segar adalah tampak mengering dan ditumbuhi jamur sebagai akibat dari kontaminasi pada saat penanganan pascapanen. Dengan demikian, perlu dilakukan penelitian tentang perubahan fisik jagung manis segar selama penyimpanan. Oleh karena itu, tujuan penelitian ini adalah membandingkan pengaruh jenis kemasan dan suhu penyimpanan terhadap karakteristik fisik jagung manis segar selama penyimpanan.

\section{METODE PENELITIAN}

\section{Alat dan Bahan Penelitian}

Peralatan yang digunakan terdiri atas timbangan digital, lemari pendingin merek Sanyo, moisture analyzer merek Mettler Toledo, color meter merek AYI, dan termometer. Sedangkan bahan yang digunakan adalah jagung manis segar varietas Super Sweet berumur 1 hari setelah 
panen yang dibeli langsung di pasar tradisional di Kota Mataram, Nusa Tenggara Barat (NTB) (Gambar 1).

Jenis kemasan yang digunakan dipilih berdasarkan kemasan yang sudah umum dipakai oleh pedagang jagung yaitu plastik polyprophylene $(\mathrm{PP})$ dan polyethylene $(\mathrm{PE})$ berukuran $15 \times 30 \mathrm{~cm}$ dengan kapasitas isi \pm $1 \mathrm{~kg}$. Ukuran ketebalan untuk plastik PP adalah 0,08 $\mathrm{mm}$, sedangkan plastik $\mathrm{PE}$ adalah $0,04 \mathrm{~mm}$.

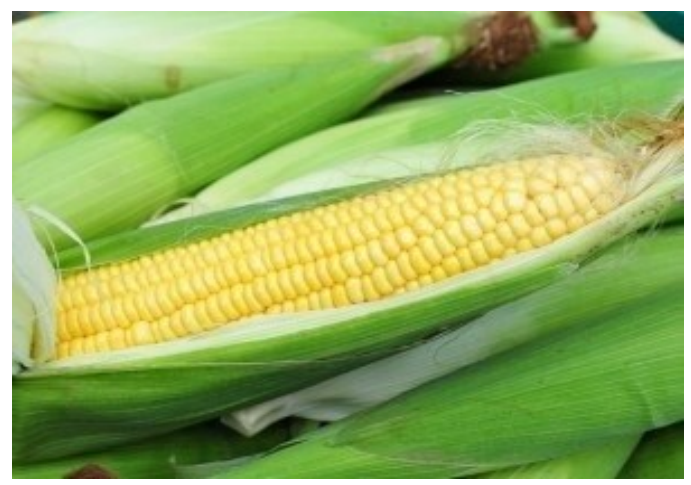

Gambar 1. Jagung Manis Segar

\section{Prosedur Penelitian}

Jagung manis segar yang sudah dibuka kulitnya berbentuk tongkolan disimpan di dalam kemasan PP dan PE masing-masing sebanyak 310 gram, kemudian disimpan pada suhu 10 dan $29^{\circ} \mathrm{C}$ selama 10 hari. Parameter yang diamati adalah kadar air, susut bobot, dan kromasitas warna. Pengukuran dilakukan setiap hari.

\section{Pengukuran Kadar Air}

Kadar air sampel diukur setiap hari menggunakan moisture analizer. Pengukuran kadar air dilakukan dengan memipil jagung kemudian menimbang berat sampel awal rata-rata 5 gram, kemudian dicacah dan dimasukkan ke dalam moisture analizer hingga kering dan mencapai bobot yang stabil (Fahroji \& Hendri, 2016).

\section{Pengukuran Susut Bobot}

Pengukuran susut bobot jagung manis segar dilakukan dengan cara menimbang sampel sebelum dan sesudah penyimpanan menggunakan Persamaan 1 (Pudja, 2009).
$S B=\frac{\mathrm{Ba}-\mathrm{Bk}}{\mathrm{Ba}} \times 100 \%$

Dengan:

$\mathrm{SB}=$ susut bobot $(\%)$

$\mathrm{Ba}=$ berat awal $(\mathrm{kg})$

$\mathrm{Bk}=$ berat akhir $(\mathrm{kg})$

\section{Pengukuran Kromasitas Warna}

Pengukuran kromasitas warna jagung manis segar dilakukan meng-gunakan alat color meter. Kromasitas warna jagung manis segar yang diukur meliputi nilai kecerahan $\left(\mathrm{L}^{*}\right)$, kromasitas warna merah hijau (a*), dan kromasitas warna biru kuning $\left(b^{*}\right)$ sesuai dengan standar internasional yang diadopsi dari CIE (Commission Internationale d'Eclairage) (Ansar, Nazaruddin, \& Azis, 2019). Pengukuran dilakukan 3 kali ulangan pada setiap variasi jenis kemasan dan suhu penyimpanan.

\section{Analisis Data}

Data hasil penelitian dianalisis menggunakan analisis sidik ragam dengan dua faktor yaitu faktor jenis kemasan dan suhu penyimpanan. Apabila hasil yang diperoleh berbeda secara signifikan, maka pengujian dilanjutkan dengan uji lanjut Duncan's Multiple Range Test (DMRT) pada taraf kepercayaan $5 \%$.

\section{HASIL DAN PEMBAHASAN}

\section{Kadar Air}

Kesegaran jagung manis sangat ditentukan oleh kadar air yang ada di dalamnya. Beberapa peneliti telah melaporkan bahwa tingkat kesegaran jagung manis dapat diketahui berdasarkan persentase kadar air yang ada di dalam jagung tersebut. Hasil pengukuran kadar air jagung manis pada variasi jenis kemasan dan suhu penyimpanan disajikan pada Gambar 2. 


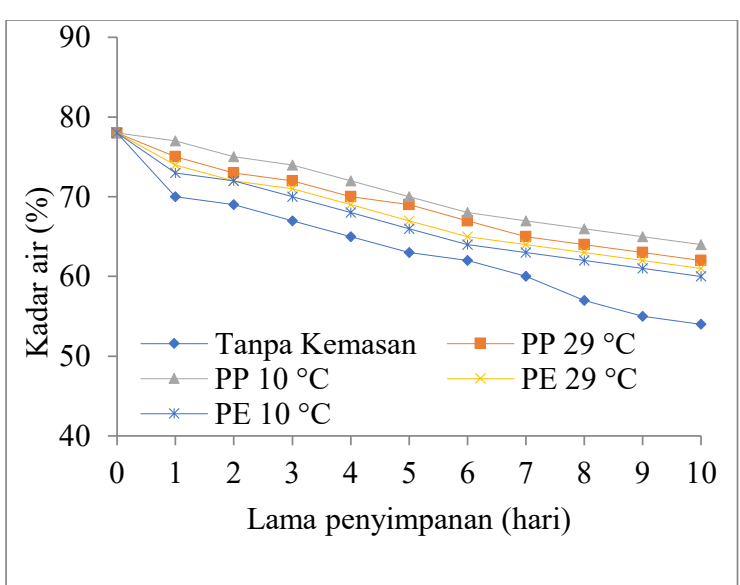

Gambar 2. Perubahan Kadar Air Jagung Manis Segar pada Variasi Jenis Kemasan dan Suhu Penyimpanan

Hasil pengamatan menunjukkan bahwa semakin lama penyimpanan, semakin menurun persentase kadar air jagung manis (Gambar 2). Persentase penurunan kadar air jagung manis terkecil terdapat pada suhu penyimpanan $10^{\circ} \mathrm{C}$, yaitu sebesar $24,75 \%$ pada kemasan PP dan $25,81 \%$ pada kemasan PE. Perbedaan penurunan persentase kadar air antara kemasan PP dan PE diduga oleh faktor ketebalan dan kerapatan. Kemasan PP memiliki ketebalan lebih besar $(0,08 \mathrm{~mm})$ dari pada PE $(0,04 \mathrm{~mm})$. Hal yang sama pernah dilaporkan Lamona et al. (2015), bahwa cabai keriting yang disimpan menggunakan plastik PP pada suhu penyimpanan $10^{\circ} \mathrm{C}$ memiliki umur simpan lebih lama yaitu sampai 29 hari dibandingkan jenis kemasan lainnya.

Persentase penurunan kadar air pada suhu penyimpanan $29^{\circ} \mathrm{C}$ untuk kemasan PP dan PE masing-masing sebesar 26,41 dan $27,60 \%$. Persentase penurunan kadar air jagung manis tertinggi didapatkan pada perlakuan tanpa kemasan yaitu sebesar $52,68 \%$. Data ini menunjukkan bahwa penurunan kadar air yang besar terjadi karena tidak ada pelindung antara sampel dengan suhu lingkungan. Proses respirasi dan transpirasi berlangsung sangat cepat, sehingga mengakibatkan laju kehilangan kadar air juga sangat cepat.

Penggunaan kemasan PP selama penyimpanan pada suhu $10^{\circ} \mathrm{C}$ dapat menghambat penguapan kadar air jagung manis, sehingga kehilangan kadar air lebih kecil jika dibandingkan dengan kemasan PE. Hasil penelitian yang sama pernah dilaporkan oleh Khathir et al. (2015), bahwa laju penurunan kadar air jagung manis berkaitan dengan proses respirasi, semakin lama proses respirasi, maka kadar air di dalam jagung manis akan semakin berkurang.

Berdasarkan analisis sidik ragam diketahui bahwa penggunaan kemasan dan suhu yang berbeda berpengaruh secara signifikan $(\mathrm{P}<0,05)$ terhadap penurunan kadar air, namun interaksi antara keduanya tidak berpengaruh secara signifikan $(\mathrm{P}>0,05)$ terhadap penurunan kadar air selama penyimpanan. Hasil uji lanjut DMRT menunjukkan bahwa penurunan kadar air jagung manis segar dalam kemasan PP lebih rendah dibandingkan kemasan PE. Hal ini diduga karena kemasan PP lebih tebal dari pada kemasan PE.

\section{Susut Bobot}

Susut bobot merupakan salah satu kriteria untuk menentukan kualitas suatu produk. Susut bobot jagung manis segar dapat disebabkan oleh kehilangan kadar air melalui proses penguapan selama penyimpanan.

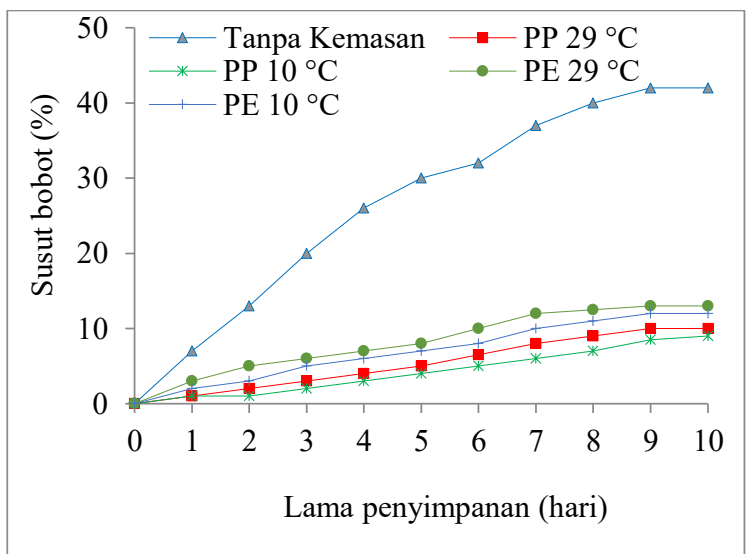

Gambar 3. Perubahan Susut Bobot Jagung Manis Segar pada Variasi Jenis Kemasan dan Suhu Penyimpanan

Susut bobot jagung manis segar terjadi seiring dengan lamanya proses penyimpanan (Gambar 3). Susut bobot tertinggi terjadi pada suhu penyimpanan 
$29^{\circ} \mathrm{C}$ tanpa kemasan yaitu $44,71 \%$ dan susut bobot terendah terjadi pada suhu penyimpanan $10^{\circ} \mathrm{C}$ menggunakan kemasan PP yaitu $26,77 \%$. Hal ini terjadi karena penyimpanan pada suhu $29^{\circ} \mathrm{C}$ tanpa kemasan terjadi proses penguapan kadar air yang sangat cepat. Kasus ini sesuai dengan pendapat Xie et al. (2017), bahwa kehilangan susut bobot jagung manis segar selama penyimpanan disebabkan oleh sebagian kadar air yang ada di dalam jaringan bahan telah menguap, sehingga jagung manis segar menjadi layu dan kering.

Penyimpanan jagung manis segar menggunakan kemasan PE dan PP pada suhu $29^{\circ} \mathrm{C}$ diperoleh susut bobot hanya sebesar 7,38 dan $6,53 \%$. Persentase yang kecil ini disebabkan oleh proses transpirasi dapat dihambat oleh kemasan. Selain itu, kelembaban relatif di dalam kemasan juga meningkat, akibatnya jagung manis segar selalu dalam kondisi lembab. Peneliti (Arnon et al., 2014) juga telah melaporkan bahwa penggunaan kemasan dapat mengurangi susut bobot karena adanya penghalang dari kemasan dan uap air sebagai hasil respirasi tertahan dan tertampung di dalam kemasan.

Dari hasil analisis sidik ragam diketahui bahwa penggunaan jenis kemasan dan suhu yang berbeda berpengaruh secara signifikan $(\mathrm{P}<0,05)$ terhadap susut bobot jagung manis segar. Namun, interaksi antara keduanya tidak berpengaruh secara signifikan nyata $(\mathrm{P}>0,05)$ terhadap susut bobot jagung manis segar selama penyimpanan. Hasil uji lanjut DMRT menunjukkan bahwa penurunan susut bobot jagung manis segar dalam kemasan PP lebih rendah dibandingkan kemasan PE. Hal ini diduga karena kemasan PP memiliki kerapatan yang lebih tinggi dari pada kemasan PE.

\section{Kromasitas Warna}

Penampakan warna dapat dijadikan sebagai salah satu indikator untuk menilai karakter fisik jagung manis segar apakah masih dalam kondisi segar atau sudah layu.
Hasil analisis sidik ragam menunjukkan bahwa penggunaan jenis kemasan dan suhu yang berbeda berpengaruh secara signifikan $(\mathrm{P}<0,05)$ terhadap kromasitas warna jagung manis segar selama penyimpanan. Namun, interaksi antara keduanya tidak berpengaruh secara signifikan $(\mathrm{P}>0,05)$ terhadap kromasitas warna jagung manis segar. Hasil uji lanjut DMRT menunjukkan bahwa perubahan kromasitas warna jagung manis segar dalam kemasan PP lebih rendah dibandingkan kemasan PE. Hal ini mengindikasikan bahwa warna jagung manis semakin pudar seiring dengan lamanya penyimpanan.

Nilai $L^{*}$ yang disimpan pada suhu $10^{\circ} \mathrm{C}$ untuk kemasan PP adalah sebesar 73,01 dan PE sebesar 73,00. Sedangkan nilai $\mathrm{L}^{*}$ pada suhu $29^{\circ} \mathrm{C}$ untuk kemasan PP sebesar 72,43 dan PE sebesar 63,59 (Gambar 4). Data ini menunjukkan bahwa jenis kemasan PP pada suhu $10^{\circ} \mathrm{C}$ dapat mempertahankan kesegaran jagung manis segar selama penyimpanan.

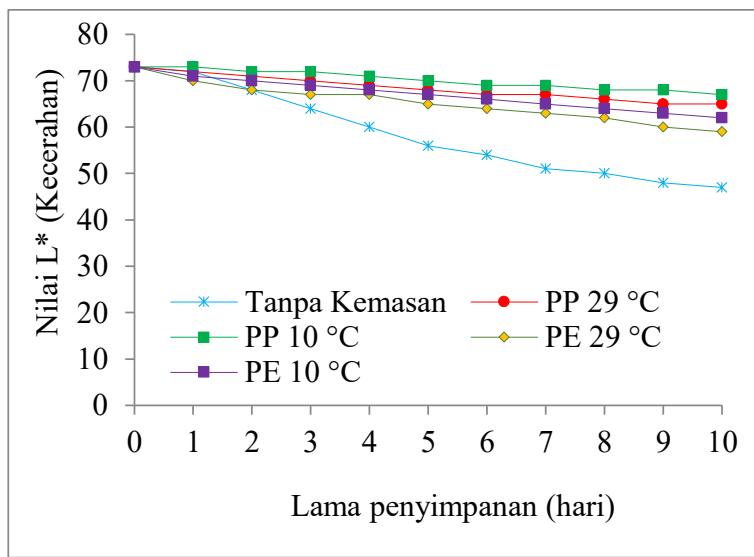

Gambar 4. Nilai Warna Kecerahan (L*) Jagung Manis Segar pada Variasi Jenis Kemasan dan Suhu Penyimpanan

Warna kromasitas merah hijau jagung manis semakin meningkat dari 15,85 menjadi 16,30 yang disimpan pada suhu $10^{\circ} \mathrm{C}$ dengan pengemas PP dan mulai mengalami kerusakan pada hari ke-8 penyimpanan dengan ciri-ciri warna sudah mulai berubah dan di ujung tongkol mulai mengalami kerusakan struktural (Gambar $5)$. 


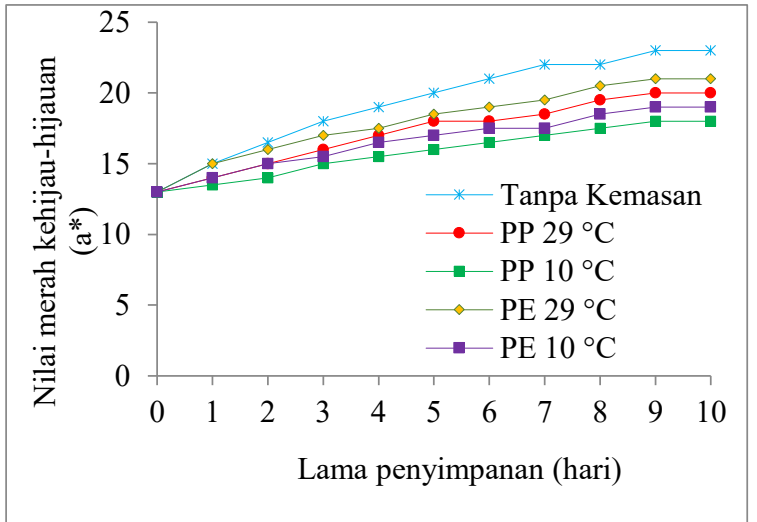

Gambar 5. Nilai Kromasitas Warna Merah Hijau (a*) Jagung Manis Segar pada Variasi Jenis Kemasan dan Suhu Penyimpanan

Pada perlakuan suhu $29^{\circ} \mathrm{C}$ dengan pengemas $\mathrm{PE}$, nilai kromasitas warna merah hijau jagung manis berubah dari 16,52 menjadi 18,23 dan kerusakan mulai terjadi pada hari ke-4 penyimpanan dengan ciri-ciri jagung manis sedikit mengkerut. Data ini menunjukkan bahwa penyimpanan pada suhu $10^{\circ} \mathrm{C}$ lebih efektif mempertahankan warna kromasitas merah hijau bila dibandingkan pada suhu $29^{\circ} \mathrm{C}$. Pendapat yang serupa pernah dilaporkan oleh Nofrida et al. (2013), bahwa untuk menahan laju perubahan kromasitas warna merah hijau pada suhu penyimpanan $10^{\circ} \mathrm{C}$ kemasan PP perlu digunakan.

Nilai kromasitas warna kuning biru (b*) jagung manis mengalami kenaikan selama penyimpanan (Gambar 6). Pada perlakuan suhu $10^{\circ} \mathrm{C}$ menggunakan bahan pengemas PE dan kemasan PP mengalami kenaikan setelah disimpan selama 10 hari, yaitu sebesar 59,94 dan 57,95. Sedangkan pada suhu $29^{\circ} \mathrm{C}$ untuk kemasan PE dan PP sebesar 61,16 dan 60,64 . Kenaikan nilai kromasitas warna kuning biru tertinggi didapatkan pada tanpa perlakuan yaitu sebesar 61,37 .

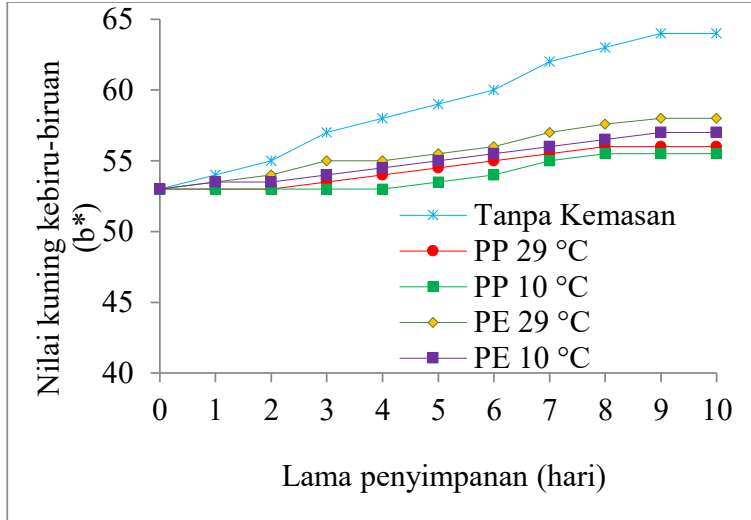

Gambar 6. Nilai Kromasitas Warna Kuning Biru (b*) Jagung Manis Segar pada Variasi Jenis Kemasan dan Suhu Penyimpanan

Nilai kromasitas warna kuning biru yang semakin meningkat menandakan bahwa jagung manis segar sudah mulai mengalami perubahan warna yaitu semakin menguning. Hal ini sesuai dengan pendapat Kumalaningsih et al (2012) bahwa pencoklatan merupakan proses pembentukan pigmen berwarna kuning dan segera berubah menjadi warna coklat gelap. Pembentukan warna coklat ini dapat dipicu oleh reaksi oksidasi dari enzim fenol.

\section{KESIMPULAN DAN SARAN}

\section{Kesimpulan}

Perbedaan jenis kemasan dan suhu penyimpanan berpengaruh secara signifikan terhadap kadar air, susut bobot, dan kromasitas warna jagung manis segar. Namun, interaksi antara keduanya tidak berpengaruh secara signifikan terhadap kadar air, susut bobot, dan kromasitas warna jagung manis segar selama penyimpanan. Penggunaan kemasan PP pada suhu $10^{\circ} \mathrm{C}$ dapat menghambat penguapan kadar air jagung manis, sehingga kehilangan kadar air lebih kecil jika dibandingkan dengan kemasan PE. Susut bobot tertinggi terjadi pada suhu penyimpanan $29^{\circ} \mathrm{C}$ tanpa kemasan $(44,71 \%)$ dan susut bobot terendah terjadi pada suhu penyimpanan $10^{\circ} \mathrm{C}$ menggunakan kemasan PP. Warna jagung manis semakin pudar seiring dengan lamanya penyimpanan. Jenis kemasan PP pada suhu $10^{\circ} \mathrm{C}$ dapat mempertahankan 
kesegaran jagung manis segar selama penyimpanan.

\section{Saran}

Kualitas fisik jagung manis segar dapat dipengaruhi oleh banyak faktor. Oleh karena itu, perlu diteliti lebih lanjut tentang pengaruh varietas dan umur jagung terhadap daya simpan jagung manis segar.

\section{UCAPAN TERIMA KASIH}

Tim Penulis menyampaikan terima kasih kepada Dekan Fakultas Teknologi Pangan dan Agroindustri Universitas Mataram atas dukungan fasilitas yang telah diberikan, sehingga penelitian ini dapat terlaksana dengan baik.

\section{DAFTAR REFERENSI}

Amanto, B. S., Atmaka, W., \& Rachmawat, D. (2011). Prediksi Umur Simpan Tepung Jagung (Zea mays L.) Instan di dalam Kemasan Plastik. Jurnal Teknologi Hasil Pertanian, 4(2), 7483.

Anggraini, R., \& Sugiarti, T. (2018). Analisis Pengemasan Jagung Manis (Zea Mays L. Saccharata Sturt) Berkelobot dengan Berbagai Bahan Pengemas. Food Tech Jurnal Teknologi Pangan, 1(1), 25-31.

Ansar, Nazaruddin, \& Azis, A. D. (2019). Pengaruh Suhu dan Lama Penyimpanan terhadap Perubahan $\mathrm{pH}$ dan Warna Nira Aren (Arenga pinnata Merr) setelah Penyadapan. Jurnal Teknik Pertanian Lampung, 8(1), 40 48.

Arnon, H., Zaitsev, Y., Porat, R., \& Poverenov, E. (2014). Effects of carboxymethyl cellulose and chitosan bilayer edible coating on postharvest quality of citrus fruit. Postharvest Biology and Technology, 87(1), 2126.

Dewi, T. K. (2015). Pengaruh Suhu dan Lama Penyimpanan terhadap Mutu Benih Jagung Manis (Zea Mays Sachaarata Strurt) di PT. Sang Hyang Seri (Persero) Sukamandi. Jurnal Agrorektan, 2(2), 117-124.

Fahroji, \& Hendri. (2016). Kinerja Beberapa Tipe Moisture Meter dalam Penentuan Kadar Air Padi. Jurnal Lahan Suboptimal, 5(1), 62-70.

Hariadi, H., Effendi, S., \& Achyad, N. S. (2017). Aplikasi Program Linear dalam Pembuatan Formulasi Cookies dari Tepung Komposit (Jagung, Kacang Kedelai dan Bonggol Pisang Batu). Jurnal Rekayasa Pertanian dan Biosistem, 5(1), 375-384.

Khathir, R., Ratna, \& Puri, M. A. (2015). Pendugaan Umur Simpan Jagung Manis Berdasarkan Kandungan Total Padatan Terlarut dengan Model Arrhenius. Agritech, 35(2), 200-204.

Kumalaningsih, S., Harijono, \& Amir, Y. F. (2012). Pencegahan Pencoklatan Umbi Ubi Jalar (Ipomoea Batatas L.) untuk Pembuatan Tepung: Pengaruh Kombinasi Konsentrasi Asam Askorbat dan Sodium Acid Pyrophosphate. Jurnal Teknologi Pertanian, 5(1), 11-19.

Lamona, A., Purwanto, Y. A., \& Sutrisno. (2015). Pengaruh Jenis Kemasan dan Penyimpanan Suhu Rendah Terhadap Perubahan Kualitas Cabai Merah Keriting Segar. Jurnal Keteknikan Pertanian, 3(2), 145-152. 
Lapanga, Hastian, \& Iswahyudi, L. (2020). Pengaruh Jenis Kemasan Plastik terhadap Perubahan Kimia, Fisik dan Organoleptik Jagung Manis (Zea Mays S.) selama Penyimpanan pada Suhu Rendah. Sultra journal of Agricultural Research, 1(1), 36-53.

Mareta, D. T., \& Nur, S. (2011). Pengemasan Produk Sayuran dengan Bahan Kemas Plastik pada Penyimpanan Suhu Ruang dan Suhu Dingin. Mediagro, 7(1), 26-40.

Maryani, A., \& Pradiana, W. (2008). Respons Masyarakat terhadap Pengemasan dan Rasa Jagung Manis. Jurnal Penyuluhan Pertanian, 3(1), 53-61.

Muhajir, R., Rahim, A., \& Hutomo, G. S. (2014). Karakteristik Fisik dan Kimia Susu Jagung Manis pada Berbagai Lama Perebusan. J. Agroland, 21(2), 95-103.

Nofriati, D., \& Asni, N. (2015). Pengaruh Jenis Kemasan dan Tingkat Kematangan Terhadap Kualitas Buah Jeruk Selama Penyimpanan. Jurnal Penelitian Pascapanen Pertanian, 12(2), 37-42.

Nofrida, R., Warsiki, E., \& Yuliasih, I. (2013). Pengaruh Suhu Penyimpanan terhadap Perubahan Warna Label Cerdas Indikator Warna dari Daun Erpa (Aerva sanguinolenta). Jurnal Teknologi Industri Pertanian, 23(3), 232-241.
Pudja, I. P. (2009). Laju Respirasi dan Susut Bobot Buah Salak Bali Segar pada Pengemasan Plastik Polyethylene selama Penyimpanan dalam Atmosfer termodifikasi. Jurnal Agrotekno, 15(1), 8-11.

Sari, D. A., \& Hadiyanto, H. (2013). Teknologi dan Metode Penyimpanan Makanan sebagai Upaya Memperpanjang Shelf Life. Jurnal Aplikasi Teknologi Pangan, 2(2), 2228.

Satmalawati, E. M., \& Rusae, A. (2017). Identifikasi Cendawan Patogen pada Penyimpanan Jagung sesuai Kearifan Lokal Masyarakat di Kabupaten Timor Tengah Utara dalam Perspektif Ketahanan Pangan. Partner, 22(1), 406-417.

Sulthoni, K. I., Susanto, W. H., \& Wijayanti, S. D. (2016). Pengaruh Pemberian Antikapang (Buffer Amilum) dan Waktu Penyimpanan Sementara terhadap Kualitas Benih Jagung Hibrida. Jurnal Pangan dan Agroindustri, 4(2), 474-482.

Xie, Y., Liu, S., Jia, L., Gao, E., \& Song, H. (2017). Effect of different storage temperatures on respiration and marketable quality of sweet corn. Advanced Engineering and Technology III, (pp. 219-224). 